\title{
PENGEMBANGAN LKPD BERBASIS MUATAN LOKAL TEKS CERITA FANTASI SMPN 1 KOTA BENGKULU
}

\author{
'Cris Diana; ${ }^{2}$ Agus Trianto; ${ }^{3}$ Agus Joko Purwadi
}

\section{Program Studi S1 Pendidikan Bahasa Indonesia Universitas Bengkulu}

\section{Abstrak}

\section{Korespondensi: crishaenadiana10@gmail.com}

Penelitian ini bertujuan untuk melakukan pengembangan lembar kerja peserta didik (LKPD) berbasis muatan lokal teks cerita fantasi untuk siswa kelas VII SMP Negeri 1 Kota Bengkulu tahun pembelajaran 2020/2021. Penelitian ini merupakan jenis penelitian dan pengembangan (reserch and development) dengan produk bahan ajar yang berjenis LKPD. Penelitian ini dilakukan dalam beberapa tahap yaitu, identifikasi masalah, tahap penelitian, tahap analisis kebutuhan, tahap pengembangan desain produk, validasi oleh ahli dan revisi. Hasil validasi dari ahli terhadap LKPD berbasis muatan lokal teks cerita fantasi untuk siswa kelas VII SMP Negeri 1 Kota Bengkulu tahun pembelajaran 2020/2021, yang dikembangkan termasuk dalam kriteria valid dengan skor 3,2 (cukup valid) dan 4,3 (sangat valid), sehingga dapat disimpulkan bahwa hasil validasi tim ahli terhadap LKPD berbasis muatan lokal teks cerita fantasi untuk siswa kelas VII SMP Negeri 1 Kota Bengkulu tahun pembelajaran 2020/2021, berada dikategori valid dan layak digunakan siswa dan guru pada proses pembelajaran.

Kata Kunci: melakukan pengembangan-mengembangkan;Research and Development.

\begin{abstract}
This study aims to develop student worksheets (LKPD) based on local content fantasy story texts for class VII students of JHS Number 1 Bengkulu City in the 2020/2021 academic year. This research is a type of research and development with the product of teaching materials type LKPD. This research was carried out in several stages namely, problem identification, research stage, needs analysis stage, product design development stage, validation by experts and revision. Validation results from experts on LKPD Based on local content fantasy story texts for class VII students of JHS Number 1 Bengkulu City in the 2020/2021 academic year, which was developed included in the valid criteria with a score of 3,2 (fairly valid) and 4,3 (very valid), so it can be concluded that the results validation of the expert team against LKPD based on local content fantasy story texts for class VII students of JHS Number 1 Bengkulu City for the 2020/2021 academic year, is in the valid and feasible category used by students and teachers in the learning process.
\end{abstract}

Keywords: do development-develop;Research and Development.

\section{PENDAHULUAN}

Kemampuan guru dalam merancang ataupun menyusun bahan ajar menjadi hal yang sangat berperan dalam menentukan keberhasilan proses belajar dan bentuk pembelajaran. Sebagai seorang pendidik perlu memiliki kemampuan dalam mengembangkan bahan ajar yang berkualitas dan inovatif. Masalah yang membuat timbulnya penelitian pengembangan ini yaitu motivasi, inovasi dan ambisi untuk mengembangkan LKPD pada guru masih kurang serta relevansi yang lemah antara 
penelitian dengan kebijakan dan praktik pendidikan. Oleh karena itu, rumusan masalah penelitian ini adalah bagaimana pengembangan lembar kerja peserta didik (LKPD) berbasis muatan lokal teks cerita fantasi untuk siswa kelas VII SMP Negeri 1 Kota Bengkulu tahun pembelajaran 2020/2021, dengan manfaat dapat memberikan inovasi terbaru pada kegiatan pembelajaran yang diharapkan dapat meningkatkan minat belajar peserta didik yang sesuai dengan tingkat pemahaman dan lingkungan peserta didik serta juga mempermudah kegiatan mengajar guru serta spesifikasi desain produk yang memiliki fungsi yang dapat meningkatkan keinginan belajar peserta didik dan mempermudah kegiatan pembelajaran dengan penampilan fisik LKPD yang rapi, menarik, sesuai dengan kurikulum, kompetensi dasar, indikator dan tujuan pembelajaran.

Produk dalam artian luas dapat berupa memperbarui produk yang telah ada (menjadi lebih praktis, efektif, dan efisien) atau menciptakan produk baru (yang sebelumnya belum pernah ada) (Sugiyono, 2019:28), sedangkan bahan ajar merupakan sesuatu yang berisi informasi serta pengetahuan yang dapat dipelajari oleh peserta didik atau siswa untuk memperoleh pengetahuan dan keterampilan yang diperlukan. Bahan ajar yang digunakan untuk memfasilitasi proses belajar maupun mengajar (Pribadi dan Putri, 2019:1.3).

Dalam hal ini, pengembangan bahan ajar yang dilakukan yaitu pengembangan Lembar Kerja Peserta Didik (LKPD). LKPD yang dikembangkan secara langsung oleh guru untuk peserta didik harus sesuai dengan keadaan peserta didik yang memiliki tingkat pemahaman, kemampuan dan lingkungan peserta didik yang berbeda-beda. LKPD itu sendiri merupakan bahan ajar cetak yang berbentuk lembaran-lembaran kertas yang memiliki materi, ringkasan, dan petunjuk-petunjuk untuk melaksanakan tugas pembelajaran yang harus dikerjakan oleh peserta didik. Menurut buku panduan kreatif membuat bahan ajar inovatif (Prastowo, 2012:205206), LKPD memiliki setidaknya empat fungsi sebagai berikut:

a. Sebagai bahan ajar yang bisa meminimalkan peran guru, namun lebih memaksimalkan peran peserta didik;

b. Sebagai bahan ajar yang dapat mempermudah peserta didik untuk memahami materi yang diberikan oleh guru.

c. Sebagai bahan ajar yang ringkas dan kaya tugas untuk peserta didik agar dapat berlatih

d. Memudahkan pelaksanaan pengajaran kepada peserta didik.

Pengembangan LKPD dengan berbasis muatan lokal merupakan program pendidikan yang isi serta media penyampaiannya dikaitkan dengan lingkungan alam, lingkungan sosial, serta lingkungan budaya dan kebutuhan daerah, sedangkan peserta didik di daerah itu wajib mempelajarinya. Dengan demikian, harus benar-benar memperhatikan karakteristik lingkungan dan juga kebutuhan daerah tersebut dalam proses perencanaan (Abdullah, 2010:260) sesuai dengan Standar Nasional Pendidikan yaitu muatan lokal untuk setiap satuan pendidikan berisi muatan dan proses pembelajaran tentang potensi dan keunikan lokal dan muatan lokal dikembangkan dan dilaksanakan pada setiap satuan pendidikan (Sulastri, 2014:14).

Materi pembelajaran yang digunakan dalam LKPD yaitu teks cerita fantasi. Teks cerita fantasi merupakan cerita yang menampilkan tokoh, alur, atau tema yang derajat kebenarannya masih diragukan, baik menyangkut (hampir) seluruh maupun hanya sebagian dari cerita, Nurgiyantoro (Yahya dkk., 2018:351). Teks yang berisi cerita fantastis yang tidak akan terjadi di dunia nyata. 


\section{METODE}

Metode penelitian yang digunakan dalam penelitian ini untuk mengembangkan LKPD adalah metode penelitian dan pengembangan atau Research and Development. Penelitian dan pengembangan atau Research and Development merupakan "a multi-faceted, complex endeavor and, while we do attempt to present some useful ideas about how it can be undertaken". Usaha yang kompleks dan beraneka segi, dan sementara kami berupaya menyajikan beberapa gagasan berguna tentang bagaimana hal itu dapat dilakukan (McKenney dan Reeves, 2012:1).

Sumber data yang diperoleh dari penelitian ini bersumber dari buku, jurnal, wawancara pada guru mata pelajaran, kuesioner untuk siswa kelas VII di SMP Negeri 1 Kota Bengkulu. LKPD yang dikembangkan divalidasi oleh dua orang ahli yang merupakan dosen dari Program Studi S1 Pendidikan Bahasa Indonesia Universitas Bengkulu. Sampel yang diambil pada penelitian ini berjumlah 60 orang siswa dengan populasi berjumlah 140 siswa perwakilan dari kelas VII di SMP Negeri 1 Kota Bengkulu.

Teknik pengumpulan data yang digunakan dalam penelitian ini yaitu menggunakan validitas konstruk (construct validity). Dengan instrumen penelitian Lembar validitas, lembar kuesioner siswa dan lembar pertanyaan wawancara guru yang berpusat pada analisis kebutuhan siswa dan guru. Teknik analisis data yang digunakan dalam penelitian ini adalah analisis validitas dengan menggunakan lembar validasi yang diberikan pada ahli, lembar kuesioner pada siswa serta wawancara pada guru mata pelajaran Bahasa Indonesia.

Pada tahap pengembangan, peneliti melakukan desain produk yang menyesuaikan isi pada LKPD itu sendiri dengan menyajikan materi, contoh soal, latihan soal beserta beberapa permainan yang dapat mengasah otak siswa dan juga sebagai salah satu daya tarik agar siswa semangat untuk belajar kemudian, uji validitas dilakukan oleh dua orang dosen Program Studi S1 Pendidikan Bahasa Indonesia Universitas Bengkulu sebagai ahli atau validator yang berpengalaman. Uji validitas yang dilakukan oleh ahli ini sebagai penilaian kelayakan pada LKPD yang dikembangkan oleh peneliti, sehingga dalam pengembangan LKPD dengan materi teks cerita fantasi ini peneliti dapat mengembangkan LKPD sesuai dengan yang dibutuhkan.

\section{HASIL DAN PEMBAHASAN}

\section{Analisis Kebutuhan}

a. Kuesioner Siswa

Data analisis kebutuhan diperoleh dari kuesioner yang diberikan pada siswa melalui google formulir yang disebarkan pada google classroom siswa. Siswa yang menjadi populasi sebanyak 140 siswa dengan sampel berjumlah 60 siswa dari 4 kelas yaitu kelas 7.4, 7.5, 7.7 dan 7.8 di SMP Negeri 1 Kota Bengkulu. Kuesioner yang diberikan pada siswa menggunakan skala Guttman dengan skala pengukuranya jawaban pada kuesioner berbentuk "ya-tidak".

Berdasarkan hasil analisis kebutuhan dengan menggunakan kuesioner yang ditujukan pada siswa diperoleh data bahwa siswa mengetahui apa itu LKPD dan masih mengingat materi teks cerita fantasi karena dalam kegiatan pembelajaran Bahasa Indonesia di kelas menggunakan LKPD. Pada kegiatan pembelajaran, dalam hal ini materi teks cerita fantasi dengan muatan lokal siswa berharap materi yang disajikan secara keseluran dengan memuat permainan dan gambar-gambar yang mendukung penjelasan materi, sehingga terlihat menarik dan dapat meningkatkan minat siswa untuk belajar. 
pada siswa:

Berikut persentase jawaban setiap pertanyaan pada angket yang telah diberikan

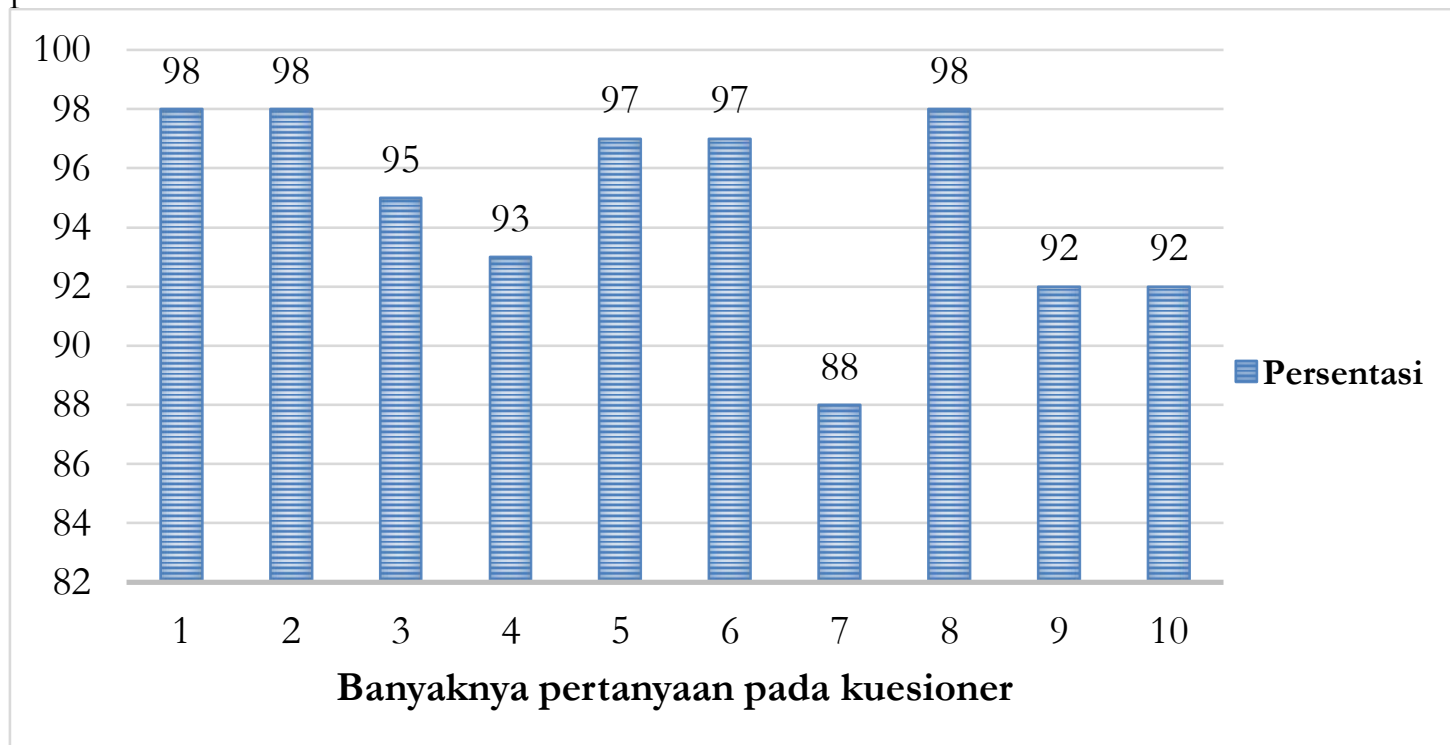

\section{Keterangan:}

1. Dari diagram batang di atas dapat disimpulkan bahwa 60 sampel dari 140 populasi terdapat 59 siswa (98\%) menjawab mereka mengetahui apa itu LKPD, sedangkan terdapat 1 siswa $(2 \%)$ yang menjawab tidak mengetahui apa itu LKPD.

2. Dari diagram batang di atas dapat disimpulkan bahwa 60 sampel dari 140 populasi terdapat 59 siswa $(98 \%)$ menjawab mereka masih mengingat materi teks cerita fantasi, sedangkan terdapat 1 siswa $(2 \%)$ yang menjawab tidak mengingat materi teks cerita fantasi.

3. Dari diagram batang di atas dapat disimpulkan bahwa 60 sampel dari 140 populasi terdapat 57 siswa $(95 \%)$ menjawab dalam kegiatan pemebelajaran di kelas pada mata pelajaran Bahasa Indonesia menggunakan LKPD, sedangkan terdapat 3 siswa (5\%) yang menjawab bahwa dalam kegiatan pemebelajaran di kelas pada mata pelajaran Bahasa Indonesia tidak menggunakan LKPD.

4. Dari diagram batang di atas dapat disimpulkan bahwa 60 sampel dari 140 populasi terdapat 56 siswa (93\%) menjawab mereka pernah membaca cerita fantasi lokal, sedangkan 4 siswa $(7 \%)$ menjawab bahwa mereka tidak pernah membaca cerita fantasi lokal.

5. Dari diagram batang di atas dapat disimpulkan bahwa 60 sampel dari 140 populasi terdapat 58 siswa (97\%) menjawab dengan adanya permainan yang menarik dalam LKPD bisa meningkatkan minat untuk belajar, sedangkan 2 siswa (3\%) menjawab bahwa dengan adanya permainan yang menarik dalam LKPD bisa meningkatkan minat untuk belajar.

6. Dari diagram batang di atas dapat disimpulkan bahwa 60 sampel dari 140 populasi terdapat 58 siswa $(97 \%)$ menjawab materi yang disajikan lebih baik secara keseluruhan, sedangkan 2 siswa (3\%) yang menjawab materi yang disajikan lebih baik tidak secara keseluruhan.

7. Dari diagram batang di atas dapat disimpulkan bahwa 60 sampel dari 140 populasi terdapat 53 siswa (88\%) menjawab materi yang disajikan dalam 
LKPD lebih baik point-pointnya saja, sedangkan 7 siswa (12\%) menjawab bahwa materi yang disajikan lebih baik tidak hanya point-pointnya saja.

8. Dari diagram batang di atas dapat disimpulkan bahwa 60 sampel dari 140 populasi terdapat 59 siswa $(98 \%)$ menjawab LKPD perlu digunakan dalam kegiatan pembelajaran, sedangkan terdapat 1 siswa $(2 \%)$ yang menjawab LKPD tidak perlu digunakan dalam kegiatan pembelajaran.

9. Dari diagram batang di atas dapat disimpulkan bahwa 60 sampel dari 140 populasi terdapat 55 siswa ( $92 \%$ ) menjawab perlu ditambahkan gambargambar yang mendukung penjelasan materi pembelajaran pada LKPD, sedangkan 5 siswa (8\%) menjawab bahwa tidak perlu ditambahkan gambar-gambar yang mendukung penjelasan materi pembelajaran pada LKPD

10. Dari diagram batang di atas dapat disimpulkan bahwa 60 sampel dari 140 populasi terdapat 55 siswa $(92 \%)$ menjawab LKPD yang pernah dikerjakan sebelumnya menarik dan bisa meningkatkan keinginan untuk belajar, sedangkan sedangkan 5 siswa ( $8 \%$ ) menjawab bahwa LKPD yang pernah dikerjakan sebelumnya tidak menarik dan tidak meningkatkan keinginan untuk belajar.

b. Wawancara Guru Mata Pelajaran

Pada sesi wawancara yang menjadi narasumber pada wawancara ini yaitu ibu Rita Ismareni, S.Pd., selaku guru mata pelajaran Bahasa Indonesia di SMP Negeri 1 Kota Bengkulu yang diwawancarai oleh peneliti yang merupakan mahasiswa Pendidikan Bahasa Indonesia Universitas Bengkulu. Wawancara dilakukan pada tanggal 8 Mei 2021, pukul 10.20 WIB, bertempat di rumah narasumber yang berlokasi di Nusa Indah.

\begin{tabular}{|c|c|c|}
\hline No. & Pertanyaan & Jawaban Narasumber \\
\hline 1. & $\begin{array}{l}\text { Bagaimana pendapat ibu } \\
\text { mengenai LKPD berbasis } \\
\text { muatan lokal? }\end{array}$ & $\begin{array}{l}\text { LKPD berbasis muatan lokal di dalamnya } \\
\text { menurut saya sangat penting, karena } \\
\text { menurut saya dizaman milenial ini di mana } \\
\text { anak-anak sedang jarang membaca dan } \\
\text { apalagi mengenal budaya lokal, sehingga } \\
\text { menjadi tahu akan budaya lokal sebagai } \\
\text { pedoman hidup dalam berbangsa, } \\
\text { beragama, dan budaya. }\end{array}$ \\
\hline 2. & $\begin{array}{l}\text { Apakah di SMP Negeri } 1 \text { Kota } \\
\text { Bengkulu ini khususnya mata } \\
\text { pelajaran Bahasa Indonesia } \\
\text { menggunakan LKPD sebagai } \\
\text { salah satu bahan ajarnya? }\end{array}$ & $\begin{array}{l}\text { Ya, kita sering menggunakan LKPD. } \\
\text { Bergantung pada kebutuhan materi yang } \\
\text { sedang diajarkan. }\end{array}$ \\
\hline 3. & $\begin{array}{l}\text { Menurut ibu, apakah perlu } \\
\text { menggunakan LKPD pada } \\
\text { proses pembelajaran? }\end{array}$ & $\begin{array}{l}\text { Sangat perlu, agar kegiatan belajar mengajar } \\
\text { lebih terarah. Ada langkah-langkah yang } \\
\text { harus dilakukan oleh peserta didik sebagai } \\
\text { langkah kegiatan pembelajaran saat itu. }\end{array}$ \\
\hline 4. & $\begin{array}{l}\text { Apakah ibu pernah tertarik } \\
\text { untuk mengembangkan LKPD } \\
\text { sendiri? }\end{array}$ & $\begin{array}{l}\text { Sangat tertarik, namun karena keterbatasan } \\
\text { waktu, sehingga LKPD yang sederhana } \\
\text { selalu dilakukan pada kegiatan peserta } \\
\text { didik. }\end{array}$ \\
\hline
\end{tabular}




\begin{tabular}{|l|l|l|}
\hline 5. & $\begin{array}{l}\text { Jika ya, mengapa dan jika tidak, } \\
\text { kenapa? }\end{array}$ & $\begin{array}{l}\text { Bagi saya LKPD sebagai petunjuk kegiatan } \\
\text { dikelas, serta dapat mengukur ketercapaian } \\
\text { kegiatan pembelajaran. }\end{array}$ \\
\hline 6. & $\begin{array}{l}\text { Menurut ibu, seperti apa LKPD } \\
\text { yang dapat meningkatkan } \\
\text { motivasi peserta didik untuk } \\
\text { giat belajar? }\end{array}$ & $\begin{array}{l}\text { LKPD yang dapat meningkatkan motivasi } \\
\text { peserta didik sebenarnya relatif. Lebih } \\
\text { banyak yang berbentuk permainan agar } \\
\text { peserta didik lebih terpancing untuk belajar. }\end{array}$ \\
\hline 7. & $\begin{array}{l}\text { Menurut ibu, apakah dengan } \\
\text { menambahkan permainan pada } \\
\text { LKPD dapat menarik perhatian } \\
\text { peserta didik untuk belajar? }\end{array}$ & $\begin{array}{l}\text { Ya, sangat baik untuk mendapatkan } \\
\text { perhatian peserta didik jika dimasukkan } \\
\text { permainan. }\end{array}$ \\
\hline 8. & $\begin{array}{l}\text { Menurut ibu, permainan yang } \\
\text { seperti apa yang dapat menarik } \\
\text { peserta didik agar bersemangat } \\
\text { dalam mengerjakan LKPD? }\end{array}$ & $\begin{array}{l}\text { Permainan seperti bermain peran, cerita } \\
\text { rumpang, sosial drama, diskusi lalu } \\
\text { laporkan. }\end{array}$ \\
\hline $\begin{array}{l}\text { Menurut ibu, dalam menyajikan } \\
\text { materi dalam LKPD lebih baik } \\
\text { disajikan secara keseluruhan } \\
\text { atau point-point pentingnya } \\
\text { saja? }\end{array}$ & $\begin{array}{l}\text { Dijelaskan secara keseluruhan namun tetap } \\
\text { harus disesuaikan dengan waktu. }\end{array}$ \\
$\begin{array}{l}\text { Apa saran ibu untuk peneliti } \\
\text { dalam pengembangan LKPD } \\
\text { yang sedang dilakukan? }\end{array}$ & $\begin{array}{l}\text { Saran saya setiap pembelajaran ada LKPD, } \\
\text { karena dapat menjadi sebagai acuan, } \\
\text { kerangka, kegiatan guru dan peserta didik } \\
\text { terpantau dan bisa mengevaluasi } \\
\text { pembelajaran pada kegiatan pembelajaran, } \\
\text { sehingga tujuan kegiatan bisa tercapai } \\
\text { karena pengembangan LKPD ini sangatlah } \\
\text { diperlukan untuk kegiatan pembelajaran } \\
\text { yang lebih baik. }\end{array}$ \\
\hline 10
\end{tabular}

Dari hasil wawancara yang telah dilakukan dapat disimpulkan bahwa pengembangan LKPD dengan memasukan budaya lokal atau muatan lokal sangatlah diperlukan. Hal ini dikarenakan agar siswa lebih mengenal budaya-budaya yang ada baik itu di daerahnya sendiri maupun yang berasal dari daerah-daerah lain yang ada di Indonesia. LKPD yang dikembangkan dengan memiliki permainan dapat meningkatkan motivasi siswa untuk belajar dengan materi yang menarik dan juga latihan dan tugas yang dapat melatih kemampuan yang dimiliki siswa.

\section{Tahap Desain Produk}

Desain produk dibuat melalui aplikasi Canva. Dengan aplikasi ini peneliti membuat sampul LKPD dan juga lembaran isi pada LKPD. Tahapan desain produk ini terdiri dari tahap pembuatan sampul, judul materi LKPD, kompetensi dasar, kompetensi isi, indikator pembelajaran, tujuan belajar dan petunjuk belajar

a. Sampul LKPD

Pada tahap ini peneliti membuat sampul LKPD yang terdiri dari judul LKPD, materi pembelajaran pada LKPD, tingkatan kelas dan semester, identitas penulis, dan identitas siswa. Dengan desain berwarna jingga yang berhiaskan berbagai gambar yang menarik. 


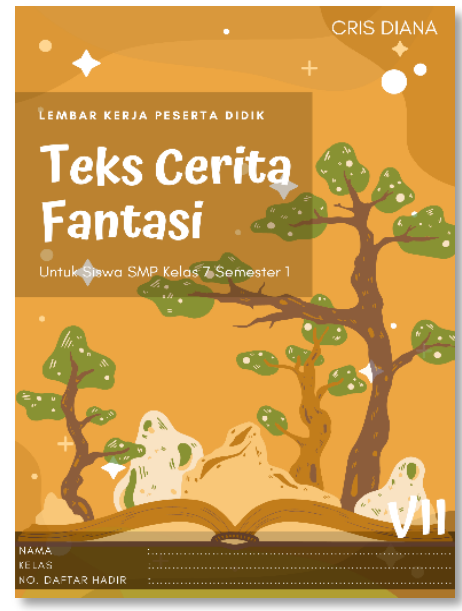

b. Kompetensi dasar dan Kompetensi isi

Pada tahap ini peneliti memilih kompetensi dasar dan kompetensi isi yang sesuai dengan materi pada LKPD dan kurikulum 2013.
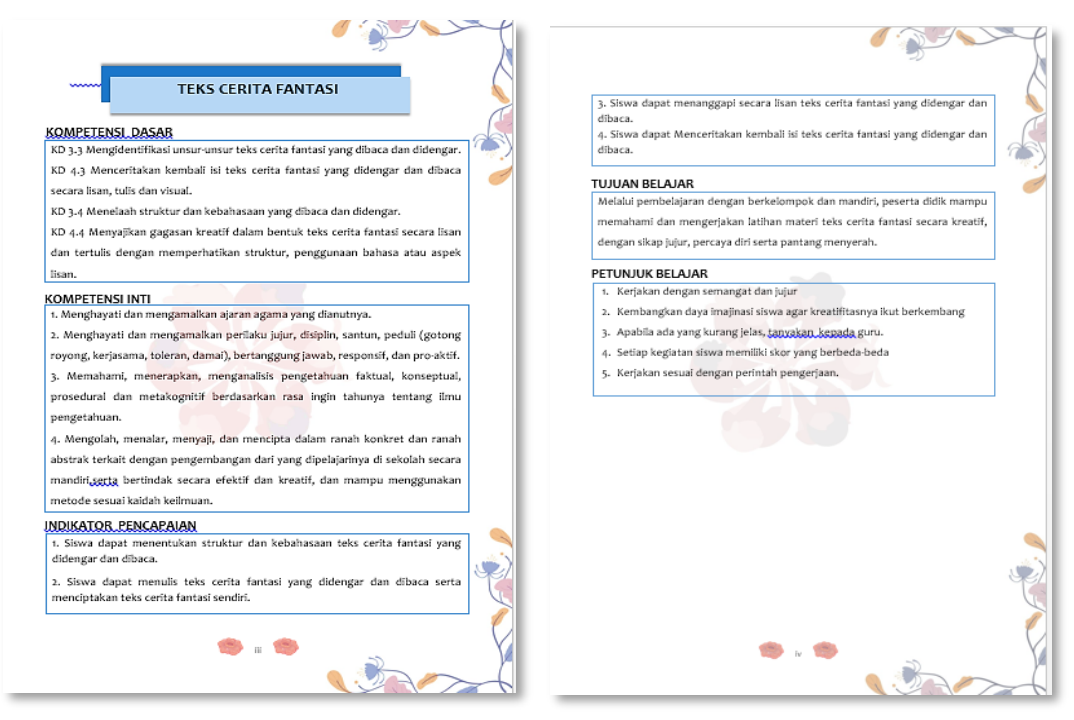

c. Indikator pencapaian

Pada tahap ini peneliti menyusun indikator pembelajaran sebagai berikut:

- Siswa dapat menentukan struktur dan kebahasaan teks cerita fantasi yang didengar dan dibaca.

- Siswa dapat menulis teks cerita fantasi yang didengar dan dibaca serta menciptakan teks cerita fantasi sendiri.

- Siswa dapat menanggapi secara lisan teks cerita fantasi yang didengar dan dibaca.

- Siswa dapat Menceritakan kembali isi teks cerita fantasi yang didengar dan dibaca.

d. Petunjuk belajar pada LKPD 
Pada tahap ini peneliti rancang agar dapat memudahkan peserta didik untuk mengerjakan LKPD berdasarkan petunjuk yang ada. Petunjuk belajar pada LKPD yaitu:

- Kerjakan dengan semangat dan jujur

- Kembangkan daya imajinasi siswa agar kreatifitasnya ikut berkembang

- Apabila ada yang kurang jelas, tanyakan kepada guru.

- Setiap kegiatan siswa memiliki skor yang berbeda-beda

- Kerjakan sesuai dengan perintah pengerjaan.

e. Lembar pengetahuan berbasis muatan lokal dan lembar membaca

Pada lembar ini peneliti merancang kotak tahukah kamu agar siswa bisa mendapatkan informasi tentang daerahnya. Peneliti juga membuat lembar membaca dengan barcode yang bisa di scan siswa melalui gawai, sehingga siswa dapat membaca cerita fantasi pada LKPD dimanapun dan kapanpun serta agar siswa tidak hanya menggunakan gawai untuk bermain namun juga bisa untuk belajar.

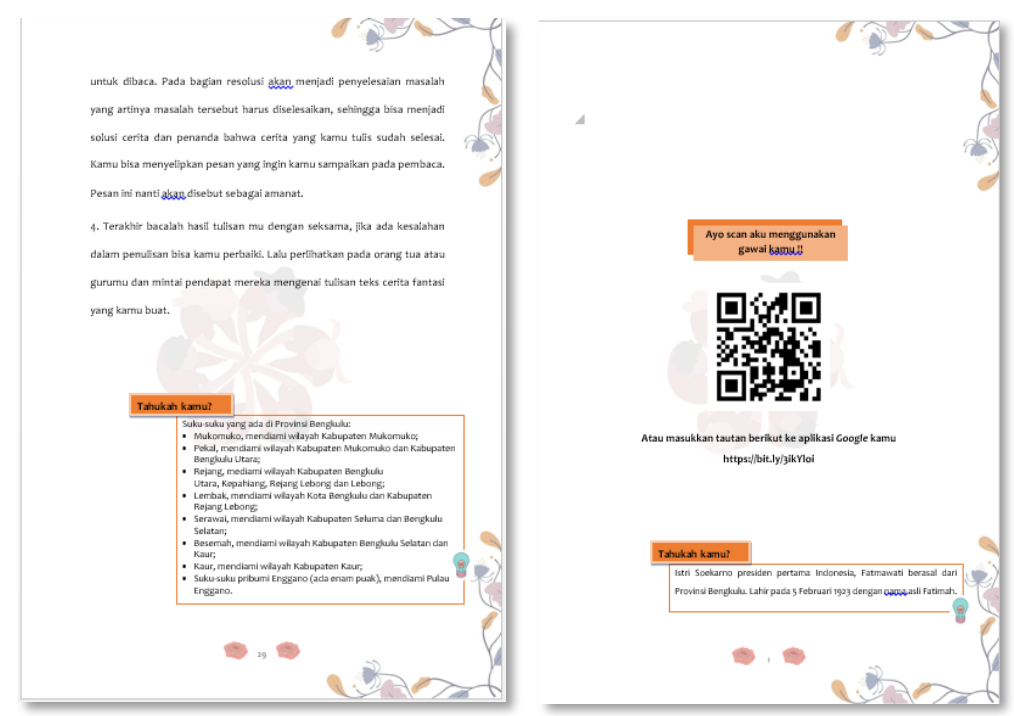

\section{Validasi LKPD}

Lembar validasi untuk LKPD merupakan instrumen penelitian sebagai alat untuk memperoleh data penelitian mengenai penilaian ahli mengenai rancangan LKPD yang dikembangkan. Dengan dilakukannya validasi, peneliti dapat mengetahui bagian yang memiliki kekurangan dalam LKPD yang dikembangkan, sehingga dapat dijadikan bahan acuan pada tahap merevisi LKPD.

Dalam penelitian dan pengembangan ini uji validitas pada LKPD yang dikembangakan dilakukan oleh dua orang dosen Program Studi S1 Pendidikan Bahasa Indonesia Universitas Bengkulu sebagai ahli atau validator yang berpengalaman. Uji validitas yang dilakukan oleh ahli ini sebagai penilaian kelayakan pada LKPD yang dikembangkan oleh peneliti. Berikut aspek pada lembar validasi yang diberikan pada ahli. 


\begin{tabular}{|c|c|c|c|}
\hline No. & Aspek & Kisi-kisi & Butir \\
\hline \multirow[t]{6}{*}{1.} & \multirow[t]{6}{*}{ Materi } & Kesesuaian dengan kompetensi dasar & 1,2 \\
\hline & & Kesesuaian dengan indikator & 3 \\
\hline & & Kesesuaian dengan kurikulum & 4 \\
\hline & & Kesesuaian dengan tujuan pembelajaran & 5 \\
\hline & & Latihan soal & 6,7 \\
\hline & & Penjelasan materi & 8,9 \\
\hline \multirow[t]{2}{*}{2.} & \multirow{2}{*}{$\begin{array}{l}\text { Konstruksi/ } \\
\text { desain }\end{array}$} & Desain LKPD & 10,11 \\
\hline & & Format LKPD & 12 \\
\hline \multirow[t]{3}{*}{3.} & \multirow[t]{3}{*}{ Bahasa } & Kaidah bahasa dalam LKPD & 13 \\
\hline & & Jenis huruf & 14 \\
\hline & & Penyampaian yang komunikatif & 15 \\
\hline
\end{tabular}

Untuk mengetahui kriteria tingkat validitas LKPD yang dikembangkan, berikut tabel kriteria penilaian validitas LKPD.

\begin{tabular}{|c|c|}
\hline Skor & Kriteria \\
\hline $1-1,8$ & Tidak valid \\
\hline $1,9-2,6$ & Kurang valid \\
\hline $2,7-3,4$ & Cukup valid \\
\hline $3,5-4,2$ & Valid \\
\hline $4,3-5$ & Sangat valid \\
\hline
\end{tabular}

(Rachmawati, 2019:164)

a. Hasil Validasi LKPD oleh Dr. Arono, M.Pd.

$$
\begin{gathered}
\mathrm{V}=\frac{\text { Total skor yang diperoleh }}{\text { Banyak data }} \\
\mathrm{V}=\frac{49}{15} \\
\mathrm{~V}=3,2 \text { (Cukup valid) }
\end{gathered}
$$

Berdasarkan hasil validasi yang dilakukan oleh Bapak Dr. Arono, M.Pd., pada tanggal 20 Juni 2021, LKPD yang dikembangkan oleh peneliti memperoleh skor validasi 3,2 (cukup valid). Dengan komentar dan saran secara keseluruhan yaitu, tulis LKPD sesuai dengan sintaks LKPD berdarakan teori Peneliti. Perbaiki penataan dan penyajian setiap tampilan. Usahakan perbanyak latihan dibanding dengan konsep atau materi. Perhatikan penyajian gambar dan warna agar lebih menarik dan jelas, sehingga dapat disimpulkan LKPD yang dikembangkan masuk pada kategori cukup valid dan dapat digunakan dalam pembelajaran, namun perlu dilakukan revisi.

b. Hasil Validasi LKPD oleh Rio Kurniawan, M.Pd.

$$
\begin{gathered}
\mathrm{V}=\frac{\text { Total skor yang diperoleh }}{\text { Banyak data }} \\
\mathrm{V}=\frac{65}{15}
\end{gathered}
$$




$$
\mathrm{V}=4,3 \text { (Sangat valid) }
$$

Berdasarkan hasil validasi yang dilakukan oleh Bapak Rio Kurniawan, M.Pd., pada tanggal 4 Agustus 2021, LKPD yang dikembangkan oleh peneliti memperoleh skor validasi 4,3 (sangat valid). Dengan komentar dan saran secara keseluruhan yaitu, penerapan HOTS dalam LKPD masih sangat kurang, lebih dominankan lagi penerapan HOTS.

\section{Revisi Produk Pengembangan}
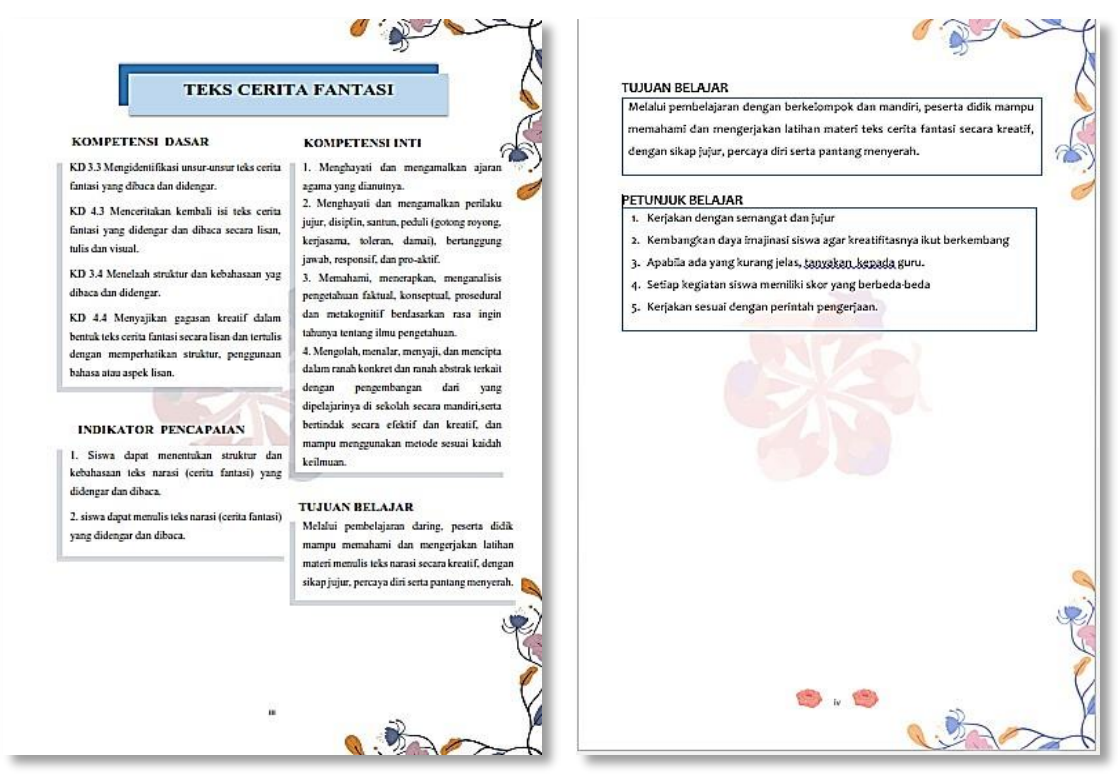

Sebelumnya petunjuk belajar tidak ada, namun setelah direvisi petunjuk belajar pun tersedia untuk memudahkan siswa menggunakan LKPD.
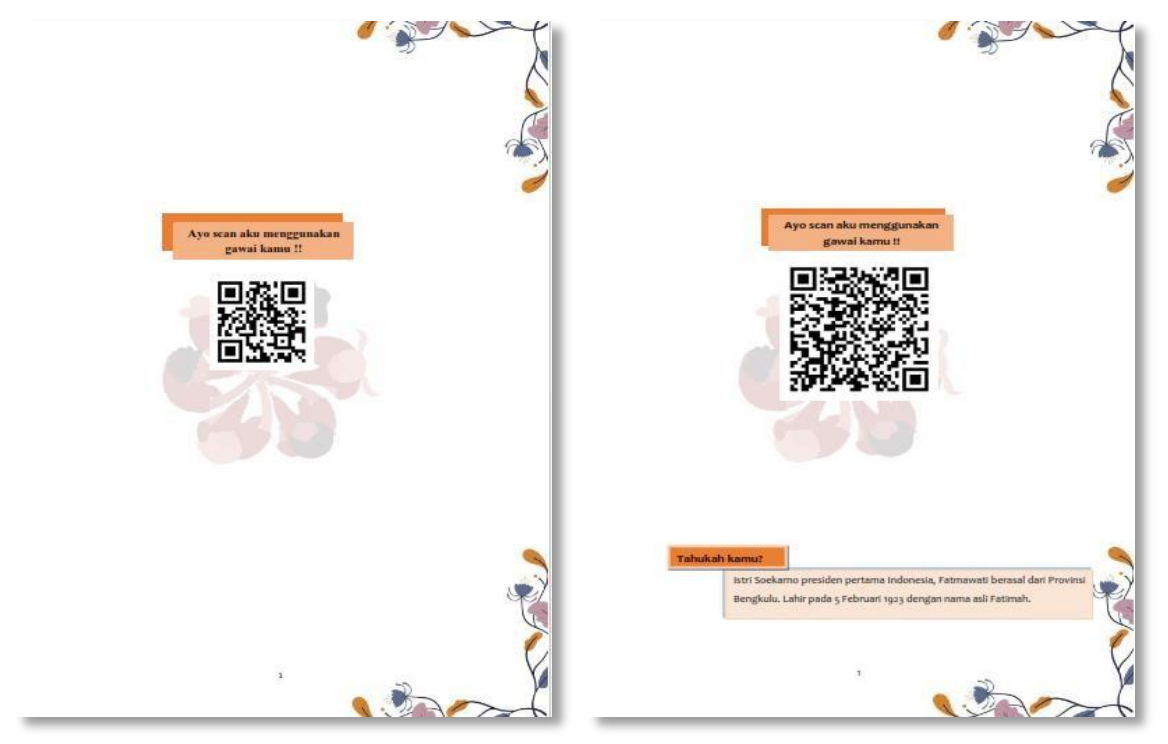

Sebelumnya tidak ada kotak pengetahuan tahukah kamu pada lembar 
membaca, namun setelah direvisi kotak pengetahuan tahukah kamu tersedia di bawah barcode.
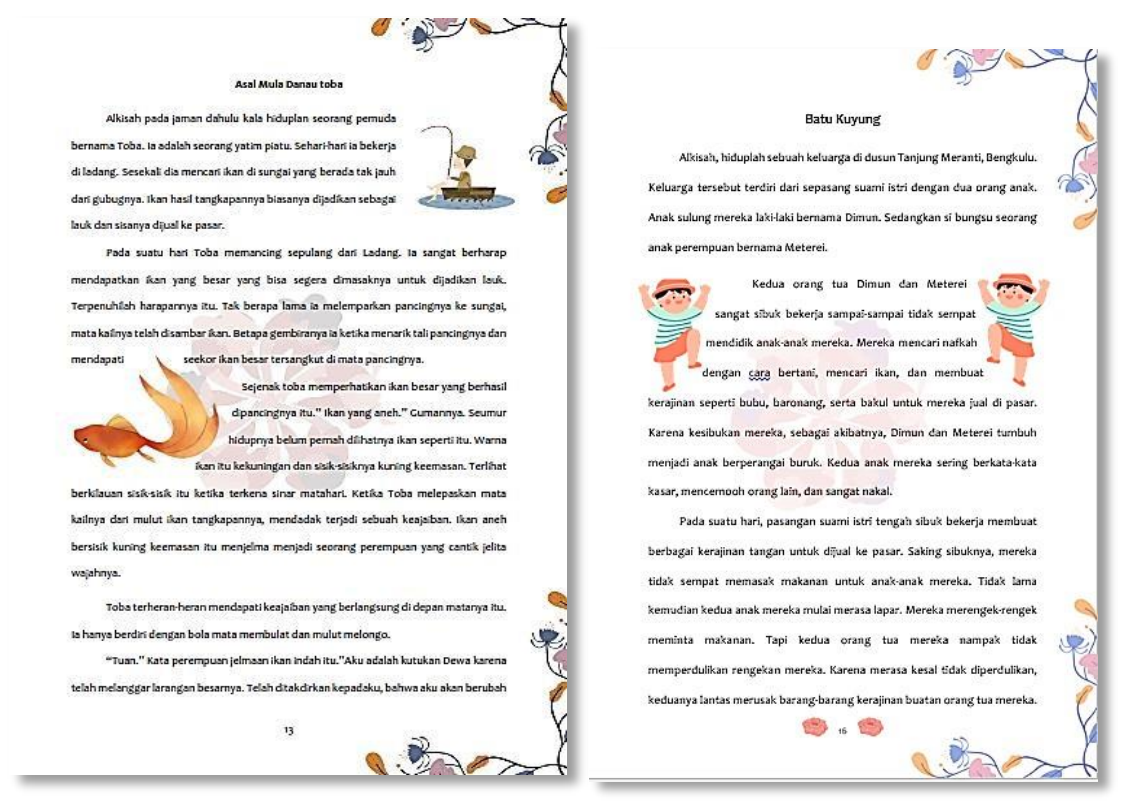

Cerita fantasi danau toba digantikan oleh cerita fantasi Batu Kuyung pada LKPD.

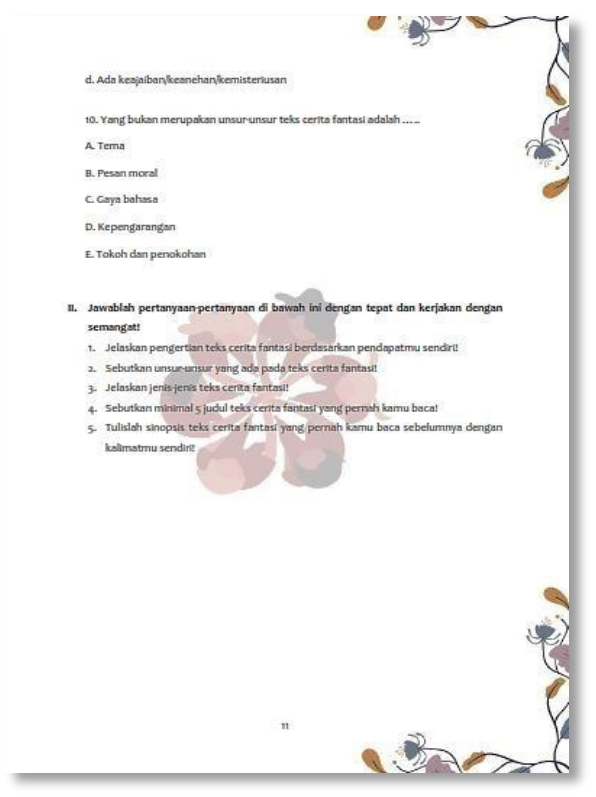

Sebelumnya uji kompetensi dua tidak ada, namun setelah direvisi peneliti menambahkan uji kompetensi dua untuk memperbanyak soal yang dapat digunakansiswa untuk melatih kemampuannya. 


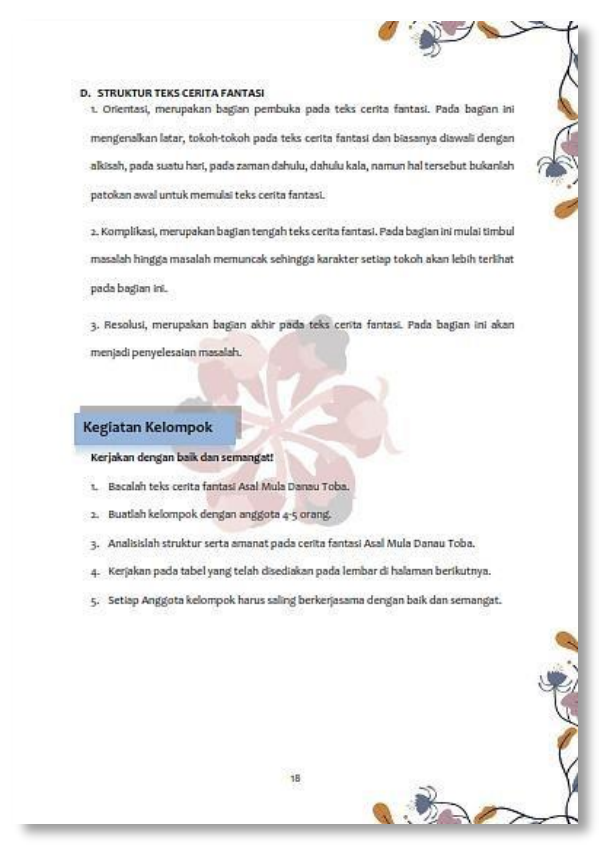

Sebelumnya kegiatan kelompok tidak ada, namun setelah direvisi peneliti menambahkan kegiatan kelompok untuk melatih kemampuan kerjasama dan pengetahuan peserta didik terhadap materi yang telah disajikan

\section{PENUTUP}

Kesimpulan

Berdasarkan hasil data penelitian yang telah dilakukan dapat disimpulkan bahwa siswa dan guru membutuhkan LKPD pada kegiatan pembelajaran. Hasil validasi yang dilakukan oleh dua orang ahli menyatakan bahwa LKPD yang dikembangkan mendapatkan skor rata-rata 3,75, dengan kriteria valid, sehingga dapat digunakan oleh siswa dan guru dalam kegiatan pembelajaran.

\section{Saran}

Penelitian dan pengembangan pada LKPD materi teks cerita fantasi ini diharapkan dapat menjadi bahan literasi dan rujukan bagi para pembaca, sehingga dapat dilakukan penelitian dan pengembangkan LKPD lebih lanjut agar LKPD menjadi lebih sempurna demi kebaikan dan kemajuan dunia pendidikan. Peneliti juga menerima kritik dan saran dari pembaca.

\section{DAFTAR RUJUKAN}

Abdullah. 2010. Pengembangan Kurikulum: Teori dan Praktek. Jogjakarta: Ar-Ruzz Media. Benny Agus Pribadi dan Dewi A. Padmo Putri. 2019. Pengembangan Bahan Ajar. Banten: Universitas Terbuka.

Prastowo, Andi. 2012. Panduan kreatif membuat bahan ajar inovatif. Jogjakarta: Diva Press. Sugiyono. 2019. Metode Penelitian dan Pengembangan Research and Development. Bandung: Alfabeta, cv. 
Sulastri. 2014. Pembelajaran Muatan Lokal Pendidikan Lingkungan Hidup dengan Model Pembelajaran Group Investigation untuk SMA/MA. Jurnal Pendidikan Sains, 12 dan 14.

Susan McKenney dan Thomas C. Reeves. 2012. Conducting Educational Design Research (p. 1). 2 Park Square, Milton Park, Abingdon, Oxon: Routledge.

Yindri Yahya, Didi Yulistio, dan M. Arifin. 2018. Kemampuan Menulis Tekes Cerita Fantasi Siswa Kelas VII. Jurnal Ilmiah Korpus, 351.

Yulia Rachmawati, Syafdi Maizora, Della Maulidiya. 2019. Validitas Lembar Kerja Peserta Didik (LKPD) Berbasis Discovery Validitas Lembar Kerja Peserta Didik (LKPD) Berbasis Discovery Smp Negeri 1 Bengkulu Tengah. Jurnal Penelitian Pembelajaran Matematika Sekolah (JP2MS), 164. 
